\title{
The Effect of Rifampicin on the Stability of the Messenger Ribonucleic Acid of Bacillus amyloliquefaciens as determined by DNA:RNA Hybridization
}

\author{
By G. COLEMAN AND S. BROWN* \\ Department of Biochemistry, University Hospital and Medical School, \\ Clifton Boulevard, Nottingham $\mathrm{NG}_{7} 2 \mathrm{UH}$
}

(Received 28 May 1975; revised I August 1975)

SUMMAR Y

Rifampicin at a concentration of $10 \mu \mathrm{g} / \mathrm{ml}$ completely inhibited protein synthesis in exponential-phase cultures of Bacillus amyloliquefaciens. At this same concentration the drug was shown to have no effect on the stability of mRNA, determined as the functional and hybridizable material, when compared with hybridizable mRNA in an uninhibited system. In each case, the half-life of the mRNA had a value in the range $5 \pm \mathrm{I} \mathrm{min}$, at $30^{\circ} \mathrm{C}$.

\section{INTRODUCTION}

The antibiotic compound rifampicin has been known for some time as a specific inhibitor of the initiation of transcription (Sippel \& Hartmann, 1968). In this role it has been used in studies on the synthesis and stability of bacterial macromolecules (Gray \& Midgley, I97I; Leighton \& Doi, 1971).

Leighton \& Doi (197I) showed that the inhibitory effect of rifampicin on Bacillus subtilis closely resembled the inhibition observed by raising the temperature of a rifampicin-resistant temperature-sensitive RNA polymerase mutant of the same organism. Whilst attempting to repeat the experiments of Leighton \& Doi (197I), Coote, Wood \& Mandelstam (1973) observed that rifampicin had a general cytotoxic effect causing fall in oxygen consumption, gross physical damage and loss of viability in B. subtilis. These findings led Coote et al. (1973) to infer, since no direct measurements were made, that no reliable conclusions about the lifetime of mRNA can be drawn from experiments with so toxic a drug.

In view of the possible seriousness of the repercussions of such a conclusion, it would seem necessary to carry out certain control experiments, omitted by Coote et al. (1973), as a preliminary to studies on macromolecule synthesis and stability using rifampicin. The results of such experiments with Bacillus amyloliquefaciens are reported below.

\section{METHODS}

Organism. Bacillus amyloliquefaciens strain T (Welker \& Campbell, 1967) was used.

Growth conditions. The composition of the medium was: $\left(\mathrm{NH}_{4}\right)_{2} \mathrm{HPO}_{4}, 34 \mathrm{mM} ; \mathrm{KCl}$, $5 \mathrm{mM} ; \mathrm{MgSO}_{4}, \mathrm{I} \mathrm{mM} ; \mathrm{FeCl}_{3}, 0.5 \mathrm{mM} ; \mathrm{CaCl}_{2}, 0.125 \mathrm{mM} ; \mathrm{ZnSO}_{4}, 0.0125 \mathrm{~mm}$; sodium citrate,

* Present address: Laboratory of Biochemical Genetics, National Heart and Lung Institute, N.I.H., Bethesda, Maryland, U.S.A. 
2. I25 mM; trace metal ion solution (Coleman \& Elliott, I965), $0.25 \mathrm{ml} / 1$; casein hydrolysate (BDH) $0.5 \%$; yeast extract (Difco), $0.05 \%$; maltose, $1 \%(\mathrm{w} / \mathrm{v})$. The medium was adjusted to $\mathrm{pH} 7.2$ with $10 \%$ (v/v) phosphoric acid. Batches $(50 \mathrm{ml})$, contained in $250 \mathrm{ml}$ conical flasks, were loop-inoculated from an aqueous spore suspension. The cultures were incubated at $30^{\circ} \mathrm{C}$ in a gyrotory incubator-shaker (model G25, New Brunswick Scientific Co., New Brunswick, New Jersey, U.S.A.).

Measurement of $\left[{ }^{14} \mathrm{C}\right]$ uracil incorporation. The effect of rifampicin (Lepetit Pharmaceuticals Ltd, Maidenhead, Berkshire) on ${ }^{14} \mathrm{C}$-labelled uracil incorporation into RNA was determined by adding $10 \mu \mathrm{Ci}\left[2{ }^{-14} \mathrm{C}\right]$ uracil $(62 \mathrm{mCi} / \mathrm{mmol})$ to a $10 \mathrm{ml}$ sample of exponentialphase $(18 \mathrm{~h}$ ) bacterial culture contained in a $100 \mathrm{ml}$ conical flask, followed $90 \mathrm{~s}$ later by the drug, to a final concentration of $10 \mu \mathrm{g} / \mathrm{ml}$. Samples $(0 \cdot 1 \mathrm{ml})$ of the culture were taken at short intervals after the addition of radioactive uracil, during incubation with shaking at $30{ }^{\circ} \mathrm{C}$, and pipetted into ice-cold $5 \%(\mathrm{w} / \mathrm{v})$ trichloroacetic acid (TCA) $(3 \mathrm{ml})$ containing unlabelled uracil $(0.5 \mathrm{mg} / \mathrm{ml})$. The precipitates formed were collected and counted as described by Coleman \& Elliott (1965).

Measurement of $\mathrm{L}-\left[{ }^{14} \mathrm{C}\right]$ leucine incorporation. The effect of rifampicin on protein synthesis was determined by incubating a $10 \mathrm{ml}$ sample of exponential-phase culture $(18 \mathrm{~h})$ in a $100 \mathrm{ml}$ conical flask, at $30^{\circ} \mathrm{C}$, with $4 \mu \mathrm{Ci} \mathrm{L}-\left[\mathrm{U}-{ }^{14} \mathrm{C}\right]$ leucine $(25 \mathrm{mCi} / \mathrm{mmol})$ followed $5 \mathrm{~min}$ later by the drug, to a final concentration of $10 \mu \mathrm{g} / \mathrm{ml}$. Samples of the culture (0.1 ml) were taken at intervals throughout the experiment and pipetted into $3 \mathrm{ml}$ of $5 \%(\mathrm{w} / \mathrm{v})$ TCA containing $0.1 \%$ casein hydrolysate. The resulting preparations were heated in a water bath at $90^{\circ} \mathrm{C}$ for $30 \mathrm{~min}$, cooled and prepared for counting as described by Coleman \& Elliott (1965).

Rapid-labelling experiments. Exponential-phase cultures $(\mathrm{I} 8 \mathrm{~h})$ were incubated for $90 \mathrm{~s}$ with $\left[5^{-3} \mathrm{H}\right]$ uracil $(2 \mathrm{I} \mathrm{Ci} / \mathrm{mmol})$ or $\left[2-{ }^{14} \mathrm{C}\right]$ uracil $(62 \mathrm{mCi} / \mathrm{mmol})$ at $\mathrm{I} \mu \mathrm{Ci} / \mathrm{ml}$, after which the cultures were immediately centrifuged for $90 \mathrm{~s}$ at $6500 \mathrm{~g}$. The bacterial pellets sedimented were then frozen in liquid nitrogen. Cell-free extracts were subsequently prepared from the frozen pellets and the labelled RNA was isolated for hybridization studies.

Similar results were obtained irrespective of whether ${ }^{14} \mathrm{C}$-labelled or ${ }^{3} \mathrm{H}$-labelled uracil was used. It was found possible, however, to achieve higher specific radioactivities using the tritiated precursor.

'Pulse-chase' experiments. These were carried out in the same manner as the rapidlabelling experiments with the exception that a 'chase', consisting of a large excess of unlabelled uracil $(50 \mu \mathrm{g} / \mathrm{ml})$ with or without rifampicin ( $10 \mu \mathrm{g} / \mathrm{ml}$ ), was added immediately after the $90 \mathrm{~s}$ 'pulse' of radioactive uracil incorporation.

Formation of bacterial cell extracts. Bacterial cell extracts, required as the first stage in the preparations for both rapidly-labelled RNA and unlabelled rRNA, were prepared as described by Coleman (1967).

Preparation of rapidly-labelled $R N A .{ }^{14} \mathrm{C}$ - and ${ }^{3} \mathrm{H}$-labelled RNA were prepared from samples of $B$. amyloliquefaciens extracts using the procedure described by Pigott \& Midgley (1968).

Preparation of unlabelled $r R N A$. rRNA was prepared from extracts of exponentialphase $B$. amyloliquefaciens as described by Pigott \& Midgley (1968).

Preparation of denatured bacterial DNA. DNA was isolated and denatured as described by Pigott \& Midgley (1968).

Preparation of DNA-bearing filters. Nitrocellulose filters (Sartorius Membranfilter MF50, $2.5 \mathrm{~cm}$ diameter; V. A. Howe \& Co. Ltd, London) were presoaked for at least $24 \mathrm{~h}$ in ice-cold $0.01 \times$ SSC buffer (SSC buffer is $0.15 \mathrm{M}$-sodium chloride-0.015 M-sodium citrate, 
$\mathrm{pH} 7 \cdot 0$ ). They were then transferred to a Millipore sampling manifold and each washed with $50 \mathrm{ml}$ of $6 \times \mathrm{SSC}$ buffer at $4{ }^{\circ} \mathrm{C}$. Samples of denatured DNA, diluted with 2 vol. of cold Io $\times$ SSC buffer, were allowed to percolate through the filters, without suction, again at $4{ }^{\circ} \mathrm{C}$ to maximize the DNA binding. The loaded filters were washed with $50 \mathrm{ml} 6 \times \mathrm{SSC}$ buffer on each side and allowed to dry at room temperature overnight. They were then dried for a further $4 \mathrm{~h}$ at $80{ }^{\circ} \mathrm{C}$ in a vacuum oven over $\mathrm{P}_{2} \mathrm{O}_{5}$.

It was found that amounts of DNA up to $150 \mu \mathrm{g}$ would bind with $100 \%$ efficiency to the filters. With larger amounts there was a reduction in efficiency, so that to prepare a filter containing $300 \mu \mathrm{g}$ of immobilized DNA it was found necessary to load on to the filter a sample containing $350 \mu \mathrm{g}$ DNA.

$D N A-R N A$ hybridization. The hybridization of RNA to denatured DNA, immobilized on nitrocellulose membrane filters, was carried out as described by Pigott \& Midgley (I968). Thus, unless otherwise stated, a DNA-bearing filter containing either 100 or $300 \mu \mathrm{g}$ denatured DNA was incubated with Io or I $\mu \mathrm{g}$ RNA, respectively, in I $\mathrm{ml} 6 \times$ SSC buffer contained in a stoppered scintillation vial. The vials were then immersed in a water bath at $66^{\circ} \mathrm{C}$ for $20 \mathrm{~h}$ to allow the interaction between DNA and RNA to reach equilibrium. After incubation the vials were cooled in ice and the filters removed and washed on each side with $50 \mathrm{ml} 6 \times$ SSC buffer. The filters were then incubated for $\mathrm{I} \mathrm{h}$ in $2 \times$ SSC buffer containing $20 \mu \mathrm{g}$ pancreatic ribonuclease (Sigma) and Io units $\mathrm{T}_{1}$ ribonuclease (Sigma) $/ \mathrm{ml}$, both of which had been heated at $80^{\circ} \mathrm{C}$ to destroy deoxyribonuclease activity. The filters were then rewashed as described above and dried in an oven at $60^{\circ} \mathrm{C}$. The dry filters were placed in vials with scintillation fluid and counted.

Each variable in this assay was subjected to an independent examination, particular attention being paid to the suggestions of Kennell \& Kotoulas (I968). The conditions used, therefore, were those which resulted in the maximum efficiency of hybridization in the B. amyloliquefaciens system.

In all the hybridization experiments, an efficiency of hybridization correction factor was applied to all results, and each result represents the mean value from duplicate assays.

Estimation of $D N A$ and $R N A$. The concentration of nucleic acid in the various preparations was calculated from measurements of $E_{260}$ in $\mathrm{I} \mathrm{cm} \mathrm{light-path} \mathrm{silica} \mathrm{cuvettes}$ in a Unicam SP500 spectrophotometer. The extinction coefficient was always taken as $E_{1 \mathrm{em}}^{1 \%}=200$.

Radioactivity measurements. Radioactivity measurements were made using a Packard Tri-Carb liquid scintillation spectrometer (model 3375). The scintillation fluid used consisted of $0.4 \%$ PPO and $0.01 \%$ POPOP in xylene (BDH, sulphur-free). Efficiency of counting was calculated by the channel ratios method, a standard curve being prepared for each isotope using known amounts of isotope and different quantities of quenching agent.

\section{RESULTS}

Kinetics of $\left[{ }^{14} \mathrm{C}\right]$ uracil incorporation in the presence of rifampicin

The characteristics of labelled uracil incorporation into total RNA; in the presence of rifampicin, were first determined, as a necessary preliminary to an examination of the effect of the drug on the stability of mRNA under the same conditions.

An exponential-phase bacterial culture was incubated with ${ }^{14} \mathrm{C}$-labelled uracil for $90 \mathrm{~s}$, after which rifampicin was added to a concentration of $10 \mu \mathrm{g} / \mathrm{ml}$. After the addition of rifampicin, incorporation of labelled uracil continued at a declining rate until it reached a maximum value $90 \mathrm{~s}$ later (Fig. I). This was consistent with the known role of rifampicin as 


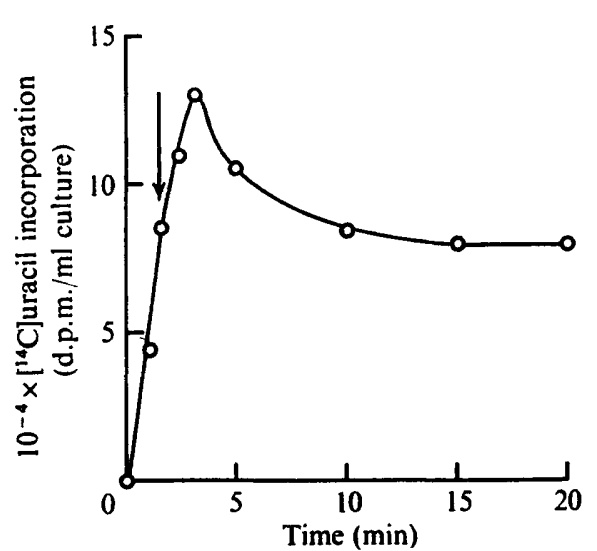

Fig. I

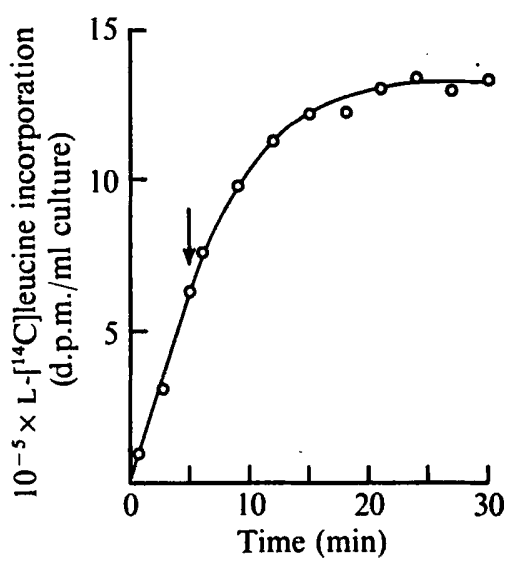

Fig. 2

Fig. I. Time course of $\left[{ }^{14} \mathrm{C}\right]$ uracil incorporation by exponential-phase bacteria in the presence of rifampicin. Rifampicin ( $10 \mu \mathrm{g} / \mathrm{ml}$ ) was added at $90 \mathrm{~s}$ (arrow).

Fig. 2. The progress of $\mathrm{L}-\left[{ }^{14} \mathrm{C}\right]$ leucine incorporation into the proteins of exponential-phase bacteria in the presence of rifampicin. Rifampicin (10 $\mu \mathrm{g} / \mathrm{ml}$ ) was added at $5 \mathrm{~min}$ (arrow).

an inhibitor of the initiation of transcription. Further, the time scale is that which would be expected if the drug exerted its inhibitory effect without a lag and allowed incorporation to continue until all the partially-formed RNA chains present at the time of addition of inhibitor were completed. Subsequently, there was a loss of radioactivity, a plateau level being reached at $6 \mathrm{I} \%$ of the maximum value. This distribution of radioactivity incorporated during the first 3 min between unstable and stable RNA species in the ratio of approximately I:2 was similar to the pattern of labelling over short time periods described by Midgley (1969).

\section{Kinetics of $\mathrm{L}-\left[{ }^{14} \mathrm{C}\right]$ leucine incorporation in the presence of rifampicin}

Evidence that the unstable RNA which decayed in the presence of rifampicin corresponded to functional mRNA was obtained from a study of the effect of the drug on the capacity of the bacteria to incorporate ${ }^{14} \mathrm{C}$-labelled leucine into protein. Exponentialphase bacteria incorporated ${ }^{14} \mathrm{C}$-labelled leucine in a linear manner in the absence of inhibition (Fig. 2). The addition of rifampicin at a concentration of $10 \mu \mathrm{g} / \mathrm{ml}$ was sufficient completely to inhibit protein synthesis, since there was a reduction in the rate of incorporation in its presence which reached a plateau level within a 30 min incubation period. At this stage, provided that it was the limiting component of the protein synthesizing system, no functional mRNA remained. The decay of unstable RNA and the loss of capacity to incorporate leucine into protein, both in the presence of rifampicin, have somewhat similar characteristics (compare Figs. I and 2).

\section{$D N A$ : RNA hybridization as a direct means of measuring $B$. amyloliquefaciens $m R N A$}

Since the ability to make meaningful direct measurements of mRNA was a key requirement in this investigation, it was of importance to demonstrate that the technique of DNA:RNA hybridization represented a specific and selective method of distinguishing mRNA from other nucleic acid components and of measuring relative changes in the mRNA content of rapidly-labelled RNA in $B$. amyloliquefaciens. 
Table I. Effect of concentration on the hybridization of rapidly-labelled RNA at low DNA: RNA ratios

Rapidly-labelled RNA was isolated from an exponentially-growing culture of $B$. amyloliquefaciens. The RNA was labelled with [ $\left.{ }^{14} \mathrm{C}\right]$ uracil for $90 \mathrm{~s}$ and hybridized with denatured DNA at DNA:RNA ratios of $5: 1$ and $10: 1$ in $\mathrm{I} \mathrm{ml}$ incubation mixtures.

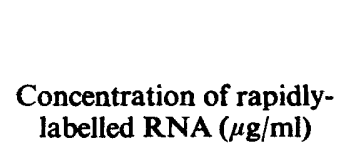
labelled RNA $(\mu \mathrm{g} / \mathrm{ml})$

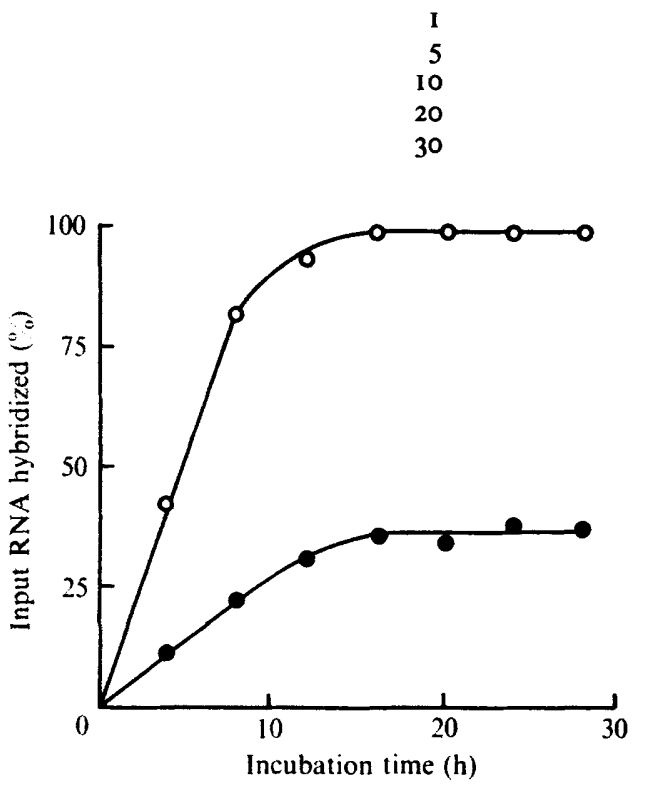

Fig. 3
Percent of rapidly-labelled RNA hybridized at DNA: RNA ratios of:

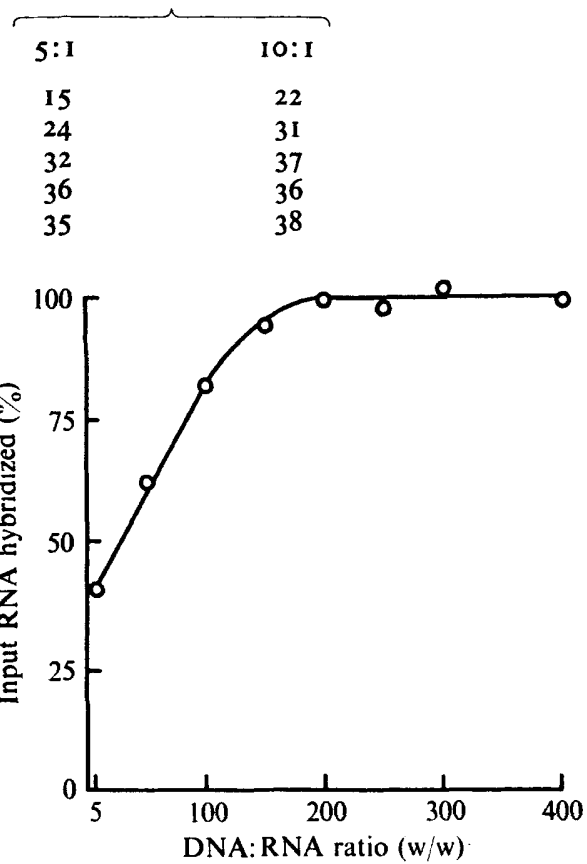

Fig. 4

Fig. 3. Time course of hybridization of rapidly-labelled RNA to denatured DNA immobilized on nitrocellulose membrane filters. The RNA was rapidly labelled with [ ${ }^{14} \mathrm{C}$ ]uracil for $90 \mathrm{~s}$ and hybridization was carried out at DNA:RNA ratios of 300:1 (O) and 10:1 (O).

Fig. 4. Hybridization of rapidly-labelled RNA from exponential-phase bacteria with increasing amounts of immobilized, denatured DNA. The RNA was rapidly labelled for $90 \mathrm{~s}$ with $\left[{ }^{14} \mathrm{C}\right]$ uracil.

The basic method and conditions adopted were those of Pigott \& Midgley (1968), whilst the precautions suggested by Kennel \& Kotoulas (1968) were applied, particularly in relation to the nucleic acid concentration effect. The percentage of the radioactivity of rapidly-labelled RNA hybridized at a DNA:RNA ratio of $10: 1$ reached a maximum value in the presence of a minimum RNA concentration of $10 \mu \mathrm{g} / \mathrm{ml}$ (Table $\mathrm{I}$ ). The details given in Methods represent the optimal conditions for hybridization in the B. amyloliquefaciens system as defined by Brown (1974). Under these conditions hybridization at both high and low DNA: RNA ratios was complete after $\mathrm{I} 6 \mathrm{~h}$ at $66^{\circ} \mathrm{C}$ (Fig. 3).

The amount of the rapidly-labelled RNA which hybridized increased with increase in DNA:RNA ratio from $39 \%$ at $5: 1$ to $100 \%$ at $200: 1$ and above (Fig. 4). This is in agreement with the findings of Midgley (1969) that at a low DNA:RNA ratio only mRNA, accounting for one-third of the rapidly-labelled material, is hybridized, all the rapidlylabelled RNA being hybridized at high DNA:RNA ratios. It can be seen in Fig. 5 that by 


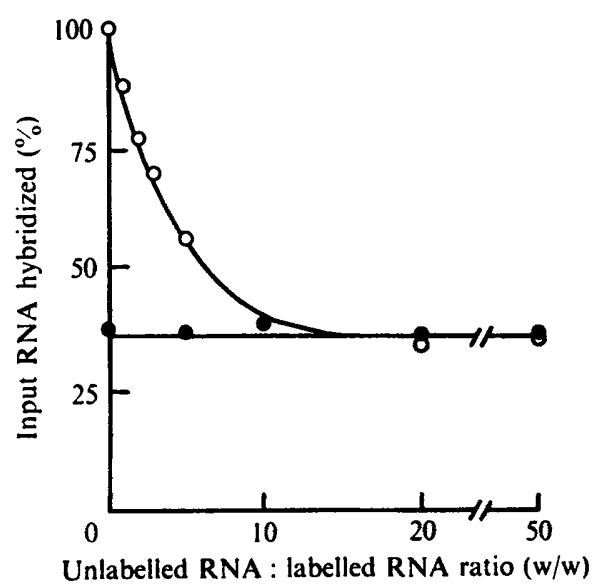

Fig. 5

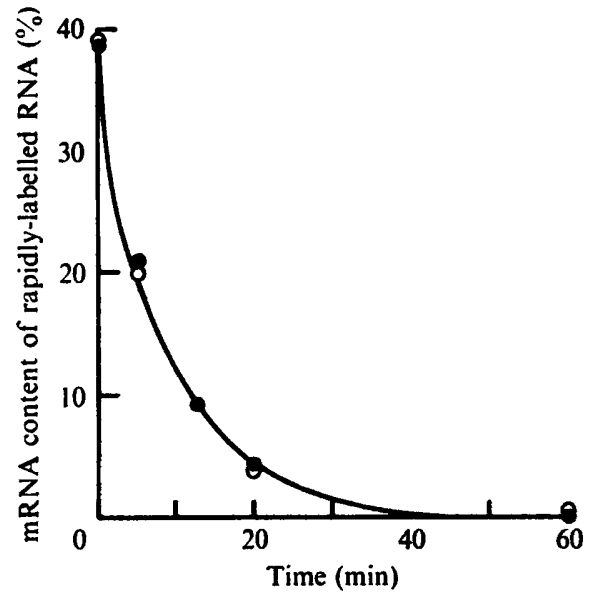

Fig. 6

Fig. 5. Effect of competition for hybridization sites on denatured DNA between rapidly-labelled total RNA and unlabelled rRNA. The RNA was rapidly labelled with [ $\left.{ }^{14} \mathrm{C}\right]$ uracil for $90 \mathrm{~s}$ and hybridization was carried out at DNA:RNA ratios of 300: I (O) and 10: 1 (O).

Fig. 6. Time course of loss of ${ }^{3} \mathrm{H}$-labelled hybridizable mRNA from exponential-phase bacteria in the absence $(O)$ and presence $(O)$ of rifampicin $(10 \mu \mathrm{g} / \mathrm{ml})$. Hybridization was carried out at a DNA:RNA ratio of I0:I.

taking the same preparation and adding increasing amounts of unlabelled ribosomal RNA there was a reduction in the hybridizable RNA detected, a plateau being reached in the presence of a 15 -fold excess of unlabelled rRNA when $39 \%$ of the input RNA was hybridized; this corresponds to the mRNA component of the rapidly-labelled material. The hybridization at a low DNA:RNA ratio was unaffected by the presence of exogenous ribosomal RNA, remaining constant at the plateau level of $39 \%$ reached by competing out all the radioactive rRNA in the high DNA:RNA system.

\section{Effect of rifampicin on the stability of $m R N A$ as determined by DNA:RNA hybridization}

The results already presented show that the mRNA component of rapidly-labelled RNA can be selectively bound during hybridization at a DNA:RNA ratio of I0:1. The means is therefore provided for assessing, by direct measurement, the effect of protein synthesisinhibiting concentrations of rifampicin on mRNA stability.

Thus, a culture of exponential-phase bacteria was divided into two identical halves each of which was given a $90 \mathrm{~s}$ 'pulse' of 'H-labelled uracil. This was followed by a 'chase' consisting of a large excess of unlabelled uracil, with or without the concomitant addition of rifampicin (I0 $\mu \mathrm{g} / \mathrm{ml}$ ). At the time of addition of the 'chase', as expected, $39 \%$ of the 'pulse-labelled' material consisted of mRNA, as determined by DNA:RNA hybridization (Fig. 6). The progress of decay of this mRNA fraction was followed, in each case, over a 60 min period; rifampicin had no detectable effect on the characteristic exponential decay pattern of the hybridizable mRNA (Fig. 6).

\section{DISCUSSION}

Over the time period of these studies (60 min), rifampicin at a concentration of $10 \mu \mathrm{g} / \mathrm{ml}$ had no detectable effect on the lifetime of functional and hybridizable mRNA at $30^{\circ} \mathrm{C}$, 
when compared with hybridizable mRNA in an uninhibited system. Thus, the mRNA halflife in each case was in the range $5 \pm \mathrm{I}$ min. Since the half-lives were the same with and without rifampicin, the decline in ability to synthesize protein shown in Fig. 2 was probably due to loss of mRNA rather than energy supply being the limiting component of the system.

In each of the present studies, carried out at a temperature of $30^{\circ} \mathrm{C}$, all the useful kinetic data was obtained well within a I h period. In contrast, Coote et al. (I973), working at $37^{\circ} \mathrm{C}$, found that at rifampicin concentrations of up to $30 \mu \mathrm{g} / \mathrm{ml}$ there was little detectable effect of the drug on the cellular morphology or oxygen uptake by the bacteria during the first hour after treatment; at this higher temperature the only dramatic short-term effect was a $95 \%$ loss of cellular viability which occurred during the first 2 min after addition of inhibitor. Thus, the principal claims of Coote et al. (1973) apply only when subjecting the bacteria to extremely high concentrations of rifampicin $(>30 \mu \mathrm{g} / \mathrm{ml})$ and after prolonged incubation periods (greater than $\mathrm{I} \mathrm{h}$ and as much as $4 \mathrm{~h}$ ).

In the absence of further experiments this provides little support for the far-reaching claim that 'no reliable conclusions about the lifetime of mRNA can be drawn from experiments with so toxic a drug'. Perhaps, a more sensible interpretation of the data would be that great care must be taken when using toxic drugs in studies involving the stability of mRNA, particularly when high concentrations are employed over prolonged incubation periods. Nevertheless, with the exercise of caution, drugs such as rifampicin can be useful tools in the study of bacterial nucleic acid metabolism when used under conditions which have been defined on the basis of the results obtained from suitable control experiments.

\section{S.B. thanks the S.R.C. for a research studentship.}

\section{REFERENCES}

Brown, S. (1974). Studies on RNA synthesis in Bacillus amyloliquefaciens. Ph.D. thesis, Nottingham University.

Coleman, G. (1967). Amino acid incorporation by a polyribosome concentrate isolated from Bacillus subtilis. Biochimica et biophysica acta 142, 558-560.

Coleman, G. \& Elliotr, W. H. (1965). Extracellular ribonuclease formation in Bacillus subtilis and its stimulation by actinomycin D. Biochemical Journal 95, 699-706.

CoOTE, J. G., WoOd, D. A. \& MANDELSTAM, J. (1973). Lethal effect of rifampicin in Bacillus subtilis as a complicating factor in the assessment of the lifetime of messenger ribonucleic acid. Biochemical Journal r34, 263-270.

Gray, W. J. H. \& Midgley, J. E. M. (1971). The control of ribonucleic acid synthesis in bacteria. The synthesis and stability of ribonucleic acid in rifampicin-inhibited cultures of Escherichia coli. Biochemical Journal 122, I6I-I69.

KenNell, D. \& Kotoulas, A. (I968). Titration of the gene sites on DNA by DNA-RNA hybridization. I. Problems of measurement. Journal of Molecular Biology 34, 7I-84.

Leighton, T. J. \& Dor, R. H. (197I). The stability of messenger ribonucleic acid during sporulation in Bacillus subtilis. Journal of Biological Chemistry 246, 3189-3195.

MidGley, J. E. M. (I969). The messenger ribonucleic acid content of Bacillus subtilis I68. Biochemical Journal 115, 17I-18I.

Pigot,, G. H. \& Midgley, J. E. M. (1968). Characterization of rapidly-labelled ribonucleic acid in Escherichia coli by deoxyribonucleic acid-ribonucleic acid hybridization. Biochemical Journal r1o, 25I-263.

StPpel, A. \& HARTMANN, G. (1968). Mode of action of rifamycin on the RNA polymerase reaction. Biochimica et biophysica acta 157, $218-219$.

WelKer, N. E. \& CAMPBell, L. L. (1967). Unrelatedness of Bacillus amyloliquefaciens \& Bacillus subtilis. Journal of Bacteriology 94, $1124-1130$. 